\title{
Critical Discourse Analysis on News Articles Regarding Large-scale Social Restriction Policy in Surabaya Government Official Website, East Java, Indonesia
}

Badrudin Kurniawan, Tjitjik Rahaju, Meirinawati, Indah Prabawati, Galih Wahyu Pradana

To Link this Article: http://dx.doi.org/10.6007/IJARBSS/v11-i1/8105

DOI:10.6007/IJARBSS/v11-i1/8105

Received: 11 November 2020, Revised: 01 December 2020, Accepted: 22 December 2020

Published Online: 04 January 2021

In-Text Citation: (Kurniawan et al., 2021)

To Cite this Article: Kurniawan, B., Rahaju, T., Meirinawati, Prabawati, I., \& Pradana, G. W. (2021). Critical Discourse Analysis on News Articles Regarding Large-scale Social Restriction Policy in Surabaya Government Official Website, East Java, Indonesia. International Journal of Academic Research in Business and Social Sciences, 11(1), 50-57.

\section{Copyright: (c) 2021 The Author(s)}

Published by Human Resource Management Academic Research Society (www.hrmars.com)

This article is published under the Creative Commons Attribution (CC BY 4.0) license. Anyone may reproduce, distribute, translate and create derivative works of this article (for both commercial and non-commercial purposes), subject to full attribution to the original publication and authors. The full terms of this license may be seen at: http://creativecommons.org/licences/by/4.0/legalcode

Vol. 11, No. 1, 2021, Pg. 50 - 57 


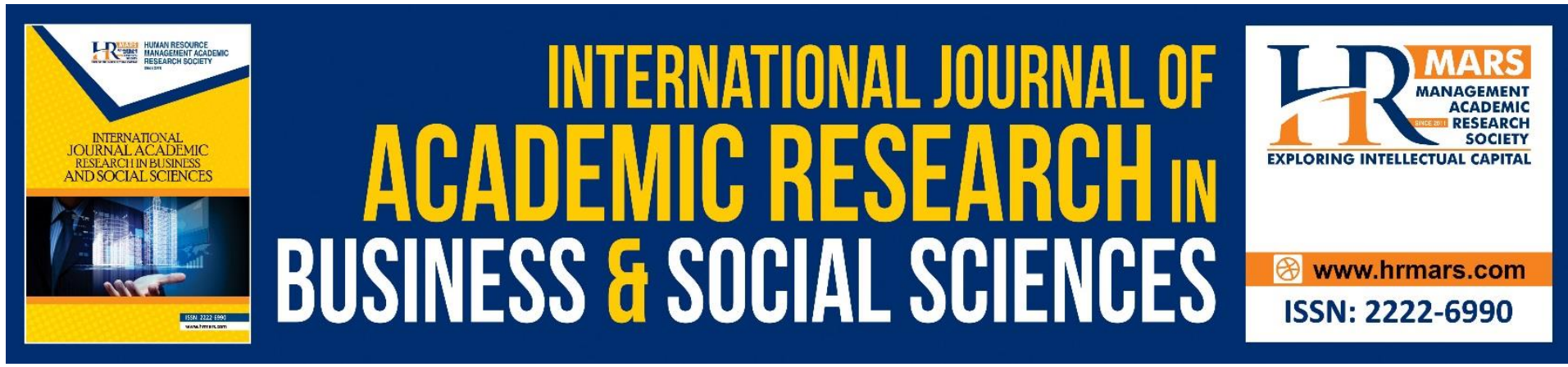

\title{
Critical Discourse Analysis on News Articles Regarding Large-scale Social Restriction Policy in Surabaya Government Official Website, East Java, Indonesia
}

\author{
Badrudin Kurniawan, Tjitjik Rahaju, Meirinawati, Indah \\ Prabawati, Galih Wahyu Pradana
}

Department of Public Administration, Faculty of Social Science and Law, Universitas Negeri

Surabaya

Email: badrudinkurniawan@unesa.ac.id

\begin{abstract}
Large-scale Social Restrictions (LSR) are one of the policies of the Indonesian government in breaking the chain of spreading Corona Virus Disease 2019 (Covid-19). This policy is implemented at the provincial and district/city scales. One of local government that has implemented this policy is Surabaya Government. A news page belonging to the government reported that Surabaya Government had complied with what the provincial government instructed, namely implementing the LSR. The government reporting is a form of persuasive policy communication. Communication through online media is able to build public opinion. In the initial LSR reporting, there was no news about LSR monitoring in industrial estates. The purpose of this study is to analyze critically discourse on the news of LSR policies on the online portal of the Surabaya City Government. The data collected by researchers are primary and secondary data. The results of this study indicate that LSR news tends to be done to build a good image of the government only. However, this tends to ignore more comprehensive coverage. The government has also been too careful about releasing news about Covid-19 when it comes to industries.
\end{abstract}

Keywords: Corona Virus Disease 2019, Large-scale Social Restrictions, Policy Communication, Government Official Website, Critical Discourse Analysis

Introduction

Asia has the most preventive and secured response to the corona virus by border controls, wearing of the face masks and making it as a routine in early January 2020 (Comite, 2020). One of the policies implemented by the Indonesian Government in dealing with the 2019 Corona Virus Disease (Covid-19) Pandemic is Large-Scale Social Restrictions (LSR). Before this policy was implemented by local government, first they should propose LSR plan to the Minister of Health. The Surabaya City Government, with the highest number of infected residents in East Java Province, has also submitted and received approval for LSR's implementation. Previously, many mass media discussed the attitude of Major of Surabaya 
Government, Tri Rismaharini, which did not immediately apply for the LSR even though this city had the highest number of Covid-19 cases in East Java Province. Media coverage sets the agenda for public debate (Wahab, Siang, Cahyowati, Wahab, \& Ph, 2020). Here are some online news related to this.

1. April $10^{\text {th }}, 2020$ : The title "Instead of LSR in Surabaya, This is Risma's Kick Against Covid-19". In this news article, the Mayor of Surabaya, Tri Rismaharini, said that the LSR or regional quarantine had actually made a mess. According to her, the most important thing is discipline to keep your distance, wear a mask, and always maintain cleanliness (Rohmat, 2020).

2. April $14^{\text {th }}, 2020$ : Title "Regional People's Representative Assembly Asks Surabaya City Government to Immediately Implement LSR". In this news article, Ibnu Shobir, a member of Commission D said that the Surabaya City Government should immediately enforce the LSR because the number of positive cases of Covid-19 continues to increase. There needs to be assistance for both Low-Income Communities and those not included in that category ("Jokowi Umumkan Dua WNI Positif Corona di Indonesia," 2020).

3. April 21 ${ }^{\text {st }}, 2020$ : Title "Regional People's Representative Assembly DPRD Doubts the Capacity of the Local Budget for the Implementation of LSR in Surabaya". In this news article, the Deputy Chairman of Regional People's Representative Assembly from the Gerindra Faction A.H. Thony, questioned the adequacy of the budget for the provision of basic foodstuffs for non-low income people. Previously, local government set a budget allocation for low income people of Rp. 161 billion (Mubyarsah, 2020).

However, the news on the official website of Surabaya Government, namely https://surabaya.go.id/id/berita, dated April 19, 2020, stated that Tri Rismaharini followed the governor's decision ("Wali Kota Risma 'Manut' Keputusan Gubernur Soal PSBB," 2020). After enacting the Mayor of Surabaya Regulation Number 16 of 2020 concerning Guidelines for Large-Scale Social Restrictions in Handling Coronavirus Disease 2019 (Covid-19) in the City of Surabaya, the news page reviews various city government activities in preparation for the implementation of the LSR. The policy will be held from 28 April 2020 to 11 May 2020 ("Wali Kota Risma 'Manut' Keputusan Gubernur Soal PSBB," 2020).

From several news released on the https://surabaya.go.id/id/berita page, there are no reviews about the preparation of assistance to overseas residents and direct monitoring of industries in Surabaya. Whereas previously it was reported that 4,242 workers in public entertainment houses were laid off. Previously, the coordination meeting between Commission D and the Surabaya Manpower Agency said that only eight companies reported having laid off 685 employees (surabaya.liputan6.com). Monitoring of the industries in Surabaya City is also important to ensure their compliance with the LSR policy. According to data from the Surabaya City Central Statistics Agency, in 2014 there were 816 medium and large industries with a total workforce of 108,803 people. Therefore the researcher is interested in conducting a research entitled Critical Discourse Analysis on News Articles regarding Large-scale Social Restriction Policy in Surabaya Government Official Website. This paper has two study objectives namely:

- To analyze critically news articles regarding LSR policy on the official website of the Surabaya City Government.

- To recommend alternative solution for the Surabaya City Government regarding policy reporting on their official website 


\section{Theoretical Framework}

There has been a lot of research on policy communication in Indonesia. This study discusses a lot about the indicators of success presented by Edward III (Lucas Sidauruk, 2014; Darmawan, Armawan, \& Haryaningsih, 2015; Nurati, 2016; Khoirul Syani, Mufid, \& Hazin, 2018). Forms of communication with good transmission, clarity and consistency of information also need to be supported by the social conditions of the community. Forms of communication based on the social conditions of the community will realize the success of policy communication.

In the era of the Industrial Revolution 4.0, policy communication carried out by the government was also conducted online. Both the central and local governments have official websites that contain a lot of information. One of the contents on the official page is the reporting of policies carried out by the government. This reporting is also a form of policy communication that has a persuasive nature because it can influence public opinion. In line with what Anderson said in Sidauruk saying that mass communication media may play an important role in shaping public opinion toward an agency by revealing and publicizing its actions, favorably or unfavorably (Lucas Sidauruk, 2014).

Policy communication studies, especially policy reporting through official government websites, are necessary. The government is able to build public opinion according to their interests. Therefore it is necessary to have a critical attitude to analyze the reporting of policies carried out by the government. In this case, the Critical Discourse Analysis approach is important to be adopted in analyzing policy reporting. By using this approach, researchers are able to uncover government interests through the text and context of online policy reporting.

\section{Research Methods}

In Eriyanto's book (Eriyanto, 2001) entitled Discourse Analysis: Introduction to Media Text Analysis, van Dijk's critical discourse analysis framework is described. CDA is suitable for research into social and cultural changes because it facilitates the integration of discourse analysis and the analysis of macro contexts (Li, Pearce, \& Low, 2018). Within this framework, there are at least three important aspects that are interrelated in shaping the meaning of discourse in online reporting of the implementation of the LSR policy by the Surabaya City Government. These three aspects include text, social cognition and social analysis. These three aspects form the basis for determining the focus of critical discourse analysis. The following are the focus of this research:

1. Discourse and textual strategies are used to describe the implementation of the LSR policy in Surabaya City

2. Cognition of journalists for the https://surabaya.go.id/id/berita page in understanding the implementation of LSR policies in the City of Surabaya

3. The discourse on implementing the LSR policy is developing in the community of Surabaya City.

The data collected by researchers are primary and secondary data. Primary data is the result of interviews with the Surabaya City Government's online portal journalists. Secondary data is in the form of online news from the Surabaya City Government and other news pages as well as comments from residents about the implementation of LSR which are recorded in the official social media of the Surabaya City Government. The secondary data in question were obtained from the period from 28 April 2020 to 11 May 2020. These data were then analyzed. Text analysis is done by identifying the structure of the text in a news article. The 
results of the interviews were analyzed to find out how the journalists viewed this issue. Furthermore, residents' comments on social media are analyzed to determine the discourse that is developing in society.

\section{Results and Discussion Text Analysis}

Discourse analysis cannot be thought without text analysis which is the micro aspects of discourse practice (Atalik, Eylul, \& Kocak, 2015; Khalid, 2020). The number of reports published from the period 28 April 2020 to 12 May 2020 with the theme LSR was 37 articles. The most articles were published on April 28, 2020 with 5 articles published on that day, the remaining 2 or 3 articles were published regularly in a period of 15 days from 28 April 2020 to 12 May 2020. From a number of articles, it can be categorized as there are 6 themes including the first theme of testing, tracing and treatment, the second theme, namely assistance for basic needs to the community, the third theme regarding incentives for business actors, the fourth theme regarding monitoring and evaluation, the fifth theme regarding others related to Covid-19 but not related to LSR policy, and the sixth theme, the last one is about others that are not related to the LSR and Covid-19.

The results of the analysis show that the city government is described as a professional, hard-working, firm and obedient party to the regulations in overcoming the Covid-19 pandemic. This imaging is done by using several elements in the news text, namely pre-assumptions and the background used by journalists to guide the direction of the narrative being made. In addition, the lexicon or choice of words is also used to support this image. For example choice of words such as epidemiological investigations, massive swab tests, taking pains, coming down to resuscitate, mass rapid tests, empowering, collaboration, verbal reprimands, written reprimands, continuing to evaluate, massive plunging, zealously giving sanctions, incessant continue to control and others. In some articles usually also use elements of coherence and intent to emphasize government actions.

\section{News Writer's Cognition Analysis}

News writers view the LSR policy as one way of dealing with the Covid-19 Pandemic. The policy is considered not only a health issue but also an economic issue. The policy is one of the strategies to break the chain of spreading Covid-19. On the other hand, it also has an impact on the economic activities of the community. The existence of this policy will have an effect on slowing down or even stopping activities for certain sectors. The impact is economic losses suffered by some of these sectors. The policy is deemed not to balance the two issues. Economic issues received less attention in implementing the LSR policy. The development and implementation of different Covid-19 protocols for specific sectors is seen as a balance between health and economic issues.

Regarding news about LSR implementation monitoring. The news tends to covering on traditional market or public facility monitoring. The monitoring of industries has received less attention. Industries, especially large industries, are considered to have consciously implemented Covid-19 protocols. However, the online news from official Surabaya Government on May 2, 2020, covered one of the large industries in the City of Surabaya has dozens of employees who have been confirmed positive for Covid-19. They can be infected by various way. The employee could be infected elsewhere. However, the number of employees who are positive for Covid-19 is quite a lot, so it is rational that news regarding of industry surveillance should be included in the news setting agenda. However, the Public 
Relations of the Surabaya City Government had conveyed that the reporting of industrial supervision was not profitable. In addition, reporting on industrial supervision was not carried out because many industries were closed during the LSR period.

\section{Social Context}

The discourse that is developing in the community of Surabaya City regarding LSR can be identified through their responses to the official social media account posts of the city government. This response can be in the form of "like" or "comment". Although the researchers conducted research on the news of LSR policies on city government official website, the responses of the people studied were on official social media accounts. This is because there is no comment column on the official website.

The Surabaya City Government has four official accounts on several types of social media, namely Facebook, Twitter, Instagram and YouTube. The official account name is "Bangga Surabaya". Of the various types of social media, the most followers are official accounts on Instagram, namely 279k (thousands) of followers. Then the official account on Facebook has 147,122 followers, Twitter with 100k followers and Youtube with 24.2k subscribers. Based on this, the researcher focused on the analysis of the public's response to the official Instagram social media account. Researchers assess that the public's response to the official Instagram account is quite representative of the discourse that is developing in society. There were 8 posts on Instagram during the first period of LSR.

The researcher examines the comments that get the most "likes". Based on the comments of the 8 posts, it is known that there are at least two things that are the main concern of the community, namely, first, compliance with the Covid-19 protocol and community support for the city government. Public attention to violations of the Covid-19 protocol, namely crowds in certain locations, such as streets, places of worship and coffee shops. Based on these comments, there is no concern for industries compliance with the Covid-19 protocol. Apart from that, the existing comments also tend to be a form of appreciation and support for the city government, especially posts on the mayor's activities. Several posts did tell about the mayor's activities to face the Covid-19 pandemic.

\section{Conclusions and Recommendations}

This study aims to do analyze critical discourse of the LSR policy reporting on the online portal of the Surabaya City Government. The results showed that the government used a textual strategy to show that the Surabaya City Government worked hard and professionally in overcoming the Covid-19 Pandemic during the first LSR period. Although it was also found that there were important elements of the LSR that did not get an adequate portion of coverage namely the local government supervision of Covid-19 protocol implementation by industries. Journalists consider the news to be less profitable for the city government. Even though the surveillance reports also show that the government ensures the Covid-19 protocol as long as the LSR can be implemented properly. In addition, through the city's official social media accounts, residents also paid attention to violations of the Covid-19 protocol committed by the community in several areas in Surabaya. This indicates that LSR reporting tends to be done to build a good image of the government only. However, this tends to ignore more comprehensive coverage. The government has also been too careful about releasing news about Covid-19 when it comes to industries.

Based on the results, several aspects of online reporting need to be improved. First, a news portal should provide an opportunity to create two-way communication between the 
government and the public. The Public Relation Department needs to add a comment column on the city government news portal. Second, image branding is also important to build public trust. However, education to the public regarding certain public policies has not been carried out optimally. There are still plenty of opportunities to do this.

This study brings benefit to development of policy communication studies. To date previous researches have lack of studies on policy communication via government official website and reveal hidden government interest on the articles. This study fills the gap. It examines several news articles on the official website and scrutinize it critically by adopting critical analysis discourse technique. For further study, researcher can portray how the news articles on government official website shape readers perception on certain policy.

\section{References}

Atalik, O., Eylul, I., \& Kocak, B. B. (2015). Discourse Analysis for Ads in Turkey: Pegasus Airlines and Anadolujet. International Journal of Academic Research in Business and Social Sciences, 5(6), 87-101. https://doi.org/10.6007/ijarbss/v5-i6/1659

Comite, U. (2020). The Impact on Businesses and Public Health Using Lock Down as a Tool against Covid-19 Pandemic in Italy: A Global Perspective. International Journal of Academic Research in Business and Social Sciences, 10(5), 394-405. https://doi.org/10.6007/ijarbss/v10-i5/7210

Darmawan, D., Armawan, S., \& Haryaningsih, S. (2015). Faktor Komunikasi Kebijakan Dalam Pengelolaan Pasar Tradisional Suatu Studi Di Kota Pontianak. Jurnal Ilmiah IImu Sosial Dan IImu Politik Universitas Tanjungpura, S-102. Retrieved from https://jurnal.untan.ac.id/index.php/jpmis/article/view/11710

Eriyanto. (2001). Analisis wacana: pengantar analisis teks media (1st ed.). Retrieved from https://books.google.co.id/books/about/Analisis_wacana.html?hl=id\&id=cpDAPMAmi $\mathrm{mcC}$

Jokowi Umumkan Dua WNI Positif Corona di Indonesia. (2020). Retrieved April 26, 2020, from cnnindonesia.com website: https://www.cnnindonesia.com/nasional/20200302111534-20-479660/jokowiumumkan-dua-wni-positif-corona-di-indonesia

Syani, K. A., Mufid, S., \& Hazin, M. (2018). Komunikasi dalam Implementasi Kebijakan Pendidikan Wajib Belajar 9 Tahun di Kecamatan Ngadiluwih. Khazanah Pendidikan, 11(1), 25-38. https://doi.org/10.30595/jkp.v11i1.2309

Khalid, N. (2020). Artificial intelligence learning and entrepreneurial performance among university students: evidence from malaysian higher educational institutions. Journal of Intelligent \& Fuzzy Systems, (Preprint), 1-19.

Li, J., Pearce, P. L., \& Low, D. (2018). Media representation of digital-free tourism: A critical discourse analysis. Tourism Management, 69(June), 317-329. https://doi.org/10.1016/j.tourman.2018.06.027

Sidauruk, L. P. (2014). Peranan Komunikasi Dalam Implementasi Kebijakan Pusat Layanan Internet Kecamatan (Kasus Di Provinsi Kepulauan Bangka Belitung ). Jurnal Penelitian Pos Dan Informatika.

Mubyarsah, L. R. (2020). DPRD Ragu dengan Kekuatan Anggaran untuk Penerapan PSBB di Surabaya. Retrieved April 26, 2020, from jawapos.com website: https://www.jawapos.com/surabaya/21/04/2020/dprd-ragu-dengan-kekuatananggaran-untuk-penerapan-psbb-di-surabaya/

Nurati, D. E. (2016). Komunikasi Kebijakan Publik Dalam Pengelolaan Pedagang Kaki Lima 
Berbasis Pada Kearifan Lokal (Kajian Pengelolaan Pedagang Kaki Lima di Kota Surakarta). JPAP: Jurnal Penelitian Administrasi Publik, 2(01), 93-106.

https://doi.org/10.30996/jpap.v2i01.701

Rohmat, H. (2020). Ketimbang PSBB di Surabaya, Ini Jurus Risma Tangkal Covid-19. Retrieved April 10, 2020, from Gatra.com website:

https://www.gatra.com/detail/news/475135/kesehatan/ketimbang-psbb-di-surabayaini-jurus-risma-tangkal-covid-19

Wahab, J. A., Siang, T. G., Cahyowati, T. D., Wahab, J. A., \& Ph, D. (2020). Media Framing on Covid-19 Pandemic in Malaysian and Indonesian Newspapers. International Journal of Academic Research In Business \& Social Sciences, 1(10), 800-812. https://doi.org/10.6007/IJARBSS/v10-i10/8016

Wali Kota Risma “Manut" Keputusan Gubernur Soal PSBB. (2020). Retrieved April 26, 2020, from surabaya.go.id website: https://surabaya.go.id/id/berita/54482/wali-kota-rismamanut-keputus 